\title{
Golfer and Tennis Elbow in Byzantine Turkey: Epicondylitis a Neglected Occupation/Activity Marker in Antiquity
}

\author{
Mark Spigelman ${ }^{1,2^{*}}$, Yilmaz S. Erdal ${ }^{3}$, Helen D. Donoghue ${ }^{1,4}$, Ron Pinhasi ${ }^{5}$ \\ ${ }^{1}$ Centre for Clinical Microbiology, University College London, London, UK \\ ${ }^{2}$ Department of Anatomy and Anthropology, Sackler Medical School, Tel Aviv University, Tel Aviv, Israel \\ ${ }^{3}$ Department of Anthropology, Hacettepe University, Ankara, Turkey \\ ${ }^{4}$ The UCL Centre for the History of Medicine, University College London, London, UK \\ ${ }^{5}$ Department of Archaeology, University College Cork, Cork, Ireland \\ Email: "spigelman@btinternet.com
}

Received October 21 $1^{\text {st }}, 2011$; revised November $24^{\text {th }}, 2011$; accepted December $15^{\text {th }}, 2011$

\begin{abstract}
Both lateral and medial epicondylitis are well known in modern medicine as diseases of occupation, leaving recognizable lesions on the epicondyles. We report on 36 individuals from the $8^{\text {th }}-10^{\text {th }}$ century AD Byzantine period from Kovuklukaya, near Sinop, Middle Black Sea region, Northern Anatolia, Turkey. The present study focuses on medial and lateral epicondylitis with lesions of enthesopathies and bony pits, assessing the frequency of these lesions in the skeletal series and whether these characters provide new and/or additional criteria for the diagnosis of activity patterns in archaeological specimens. We then discuss the significance of these lesions in interpreting the activities of past populations, possible reasons why these lesions were not previously reported by paleopathologists and the application of our findings to the assessment of activity patterns and occupational stress markers in past populations.
\end{abstract}

Keywords: Epicondylitis Lateral; Medial, Elbow; Occupational Markers; Entheses

\section{Introduction}

Examination of archaeological human bones by trained observers allows one to assess, from the marking left on the bone, the body frame of the individual and their activity during life (Benjamin et al., 2002). This has proved useful for archaeological studies. It is known that the ridges, tubercles and tuberosities that decorate bones serve for the attachment of tendons and ligaments, which are usually more conspicuous in males than in females, reflecting the greater strength of men (Bannister et al., 1995). The search for activity and occupational markers on skeletons from the past can tell us about task allocation and division of labour in a society. To understand these aspects in past populations it is important to understand the activities of present-day people and the markers they leave on bone, and then to apply this to the study of past populationssee for example studies by Masmejean et al. (1997) and Crubézy et al. (2002) on joint involvement that may be associated with changes in activities.

Hawkey and Merbs (1995) developed the term 'muscle stress markers' (MSM) to describe the markings on cortical bone at muscle and ligament attachment sites. Chapman (1997) used these markers to note changes in activity patterns in pre- and post-Spanish contact at Pecos Peublo in America. Changes in the shoulder, particularly in the acromio-clavicular joints, were recognized in populations from $16^{\text {th }}$ century Scotland and $19^{\text {th }}$ century London (Miles, 1996; 1999), suggesting that these were associated with industrialization. Numerous other studies on a variety of MSM markers have been reported (Stirland, 1991; Larsen, 1995, Al-Oumaou1 et al., 2004; Molnár, 2006; Cardoso \& Henderson 2010; Havelekova et al., 2011). In a study of

${ }^{*}$ Corresponding Author.
Neolithic (early farmers) in the Levant, changes in activity patterns were identified and quantified by the analysis of MSM in the upper limb (Eshed et al., 2004). The MSM pattern for males and females indicates a gender-based division of labour both in the Natufian and the Neolithic. In this study most of the mean MSM scores of the upper limbs are higher in the Neolithic population, suggesting that the manual workload was greater in the Neolithic Levant than during the Natufian Period. These finds are expected as activities related to a food producing, farming economy demand heavy manual work, much greater than is necessary in hunting.

Epicondylitis may be observed on both the lateral and medial epicondyle of the humerii, and the relationship between the disease and activity can be noted on living people - especially with sporting activity (Priest et al., 1977; Walker-Bone, et al., 2004). However, there are few studies and little or no evidence collected about the type and frequency of epicondylitis in past populations (Miller, 1985; Crianni \& Fornaciari, 2003). This study focuses on epicondylitis with lesions of enthesopathies and bony pits in an archaeological population from Northern Anatolia, as occupational and/or activity markers. It first reviews the anatomical and pathological aspects of the condition, then proceeds to address the indication of this condition in the Anatolian skeletal sample, and its implications to the study of this condition in other skeletal populations.

\section{Functions of Muscles Attaching to the Epicondyle}

Muscles attached to the lateral epicondyle are responsible for straightening the fingers, dorsiflexion of the wrist in and rotating the forearm with the palm uppermost (Figure 1). Muscles attached to the medial epicondyle are responsible for flexing 




Figure 1.

Anterior aspect of the distal end of the humerus indicating sites of muscle attachment on the medial and lateral epicondyles.

the fingers, palmar flexion of the wrist, and the forearm with the palm down.

Epicondylitis occurs in activities requiring repeated or forceful movements of the fingers, wrist, and forearm. Lateral epicondylitis (tennis elbow) can arise because of a single forceful act or blow. Gripping or twisting activities done repeatedly and forcefully in awkward positions without proper rest periods if done with extended arms well away from the body, can contribute to lateral epicondylitis in a modern day population. Such activities include bending of the wrist and rotating the forearm at the same time, holding an object with force for lengthy periods, and jerky throwing movements (the Canadian Centre for Occupational Health and Safety-CCOHS

http://www.ccohs.ca/oshanswers/diseases/tennis_elbow.html). Medial epicondylitis (Golfer's elbow) has similar causes but is a far less frequent problem in today's society (Barton et al., 1990). Epicondylitis leaves two visible lesions on the bony skeleton: entheses and bony pits.

\section{Entheses}

The entheses are the sites of attachment of ligaments, tendons, and joint capsules to bone. Claudepierre and Voisin (2005) noted that early in the development of a fibro-cartilaginous enthesis, the tendon attaches directly to hyaline cartilage. The hyaline cartilage undergoes endochondral ossification, where the bone gradually erodes the undersurface of the hyaline cartilage, replacing it by bony trabeculae. The end tendon cells undergo metaplasia into cartilage cells, which lay down a layer of fibro-cartilage. When this is completed, the enthesis is composed of tendon, then fibro-cartilage, and finally bone, with no hyaline cartilage. Repeated strenuous physical activities, including sporting activities, are the leading cause of symptomatic enthesopathy but age and some specific diseases may also be responsible for their development. Niepel and Sit'aj (1979) suggest that enthesopathies are the source of both symptoms and disorders of function. Gore et al. (1980) noted the following osseous manifestations of elbow stress associated with sports activities: bony hypertrophy, loose bodies, traction spur formation, osteochondral and humeral shaft fractures. In the elbow we use various terms for these changes: endostheses, endosteophytes, traction spurs, or osteophytes. As we believe these names all refer to the same process, we shall call them 'endostheses' (Figure 2).

\section{Bony Pits}

Further signs of occupational stress are pits on the bonethese are shallow "scooped out" areas which represent places where the tendons are anchored to the bone and then pulled off but will not show up on radiographs or magnetic resonance imaging (MRI). One of the authors (MS) as a surgeon performed numerous $(100+)$ operations on people suffering from both lateral and medial epicondylitis, noting where the tendon had pulled away from the epicondyle there was a certain grittiness of the ends of the tendon, which we believe must be due to small calcified entheses pulling off the epicondyle. This minor finding, of no clinical significance, is unreported and unpublished. As the operation generally involves "shaving" the epicondyle, the "scooped out" shallow scars will not be available to future paleopathologists on any patients who have had the operation; a shaved epicondyle will be the proof of past epicondylitis. One or two such pits with rounded edges may represent nutrient canals for the passage of blood vessels; however, in epicondylitis they become too numerous for us to accept this explanation.

\section{Pathology}

Physiological changes form the background of pathological changes, particularly those resulting from repeated stressing of the entheses beyond the safe limits of their capacity. The tendinous fibres rupture, the coherence of bone and cartilage is reduced, the continuity of the cartilage zone is impaired and bone may be denuded so that small portions of cartilage and

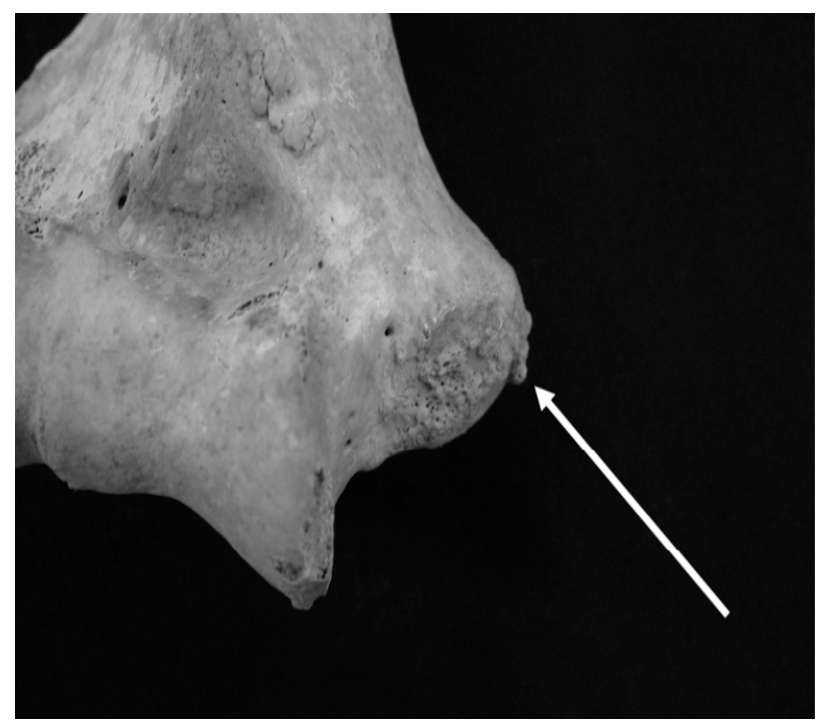

Figure 2.

The arrow points to entheses on KK'02 SK 7/2. This formation is sometimes referred to as a traction osteophyte. 
bone are separated from one another by the pull of the tendinous fibres. The damage induces repair, and reconstruction in the bone and the cartilaginous zone. A typical feature of healing zone is calcification by means of the deposition of calcium apatite into collagen fibres, together with the formation of new bone on the site of damaged cartilage and bone. This leads to the formation of enthesopathies, analogous to osteophytes in osteoarthritis (Niepel \& St'aj 1979).

\section{Materials}

Kovuklukaya is located $300 \mathrm{~m}$ to the northeast of Çulhalı village, in Sinop province, Northern Anatolia. A Byzantine cemetery was at the top of the mound; measuring $70 \mathrm{~m} \times 80 \mathrm{~m}$. Thirty-six human skeletons were unearthed in 25 rectangular pits and cist graves (Erdal, 2008). The excavated skeletal series includes 17 males, 15 females and four subadults. A radiocarbon determination of one of the skeletons a female aged 28 years has yielded a calibrated age range of 770 A.D. - 970 A.D. $\pm 2 \sigma$ (95.4\% probability). Sex of each individual was determined by cranial and post-cranial morphology based on Buikstra and Ubelaker (1994). The age at death was determined by pubic symphysis, auricular surface of the os coxae, cranial suture closure, and other metamorphic changes on the skeletons (cf. Lovejoy et al., 1985; Brooks \& Suchey, 1990; Meindle \& Lovejoy, 1985, 1989; Buikstra \& Ubelaker, 1994). Age groups were separated as young adults (15-30 years old), middle adults (30 - 45 years old) and old adults $(45+)$.

The epicondyles of 59 distal adult humerii were examined macroscopically with a hand lens $(10 \times)$. The statistical analysis of the epicondylitis, in relation to age and sex, was tested using the $\chi^{2}$ test in an SPSS 13.0 software package. Due to the limited sample size, Yates's correction was performed in the $\chi^{2}$ test; in cases when the samples were fewer than five, Fisher's exact $\chi^{2}$ test was used.

\section{Results}

Medial epicondylitis, a condition that demonstrates itself as pitting on the anterior surface of the medial epicondyle and as small-calcified entheses around the epicondyle, was observed on $25.5 \%$ of the 55 humerii from the Kovuklukaya population (Table 1). Figure 2 illustrates the condition in KK' 02 SK 7/2, a male aged about 37 - 38 years, whose skeletal remains showed signs of heavy labour. The bony pits created by the pulling away of the tendon of the left lateral epicondyle are visible, as well as a small number of entheses. The close up view of the left medial epicondyle is in Figure 3. The entheses appear as raised bony points and the few pits have quite rounded edges, suggesting some tendon tear (partial) in the past with healing. Among the overall population, approximately one out of every four humerii has medial epicondylitis. The frequency of medial epicondylitis among males (26.7\%) is slightly higher than among the females (25\%) (Table 1). Although the difference between the frequency of medial epicondylitis in males and females is not statistically significant, in general epicondylitis on the right medial epicondyles were much more severe in both sexes (Figure 4).

The surfaces of the attachment portion of medial epicondyles on young adult individuals are smooth. A higher frequency of epicondylitis was observed in middle-aged individuals, who had more pronounced bony pitting and entheses than other age
Table 1.

Distribution of medial epicondylitis in relation to sex.

\begin{tabular}{ccccccccc}
\hline & \multicolumn{2}{c}{ Right } & \multicolumn{2}{c}{ Left } & \multicolumn{2}{c}{ Total } & \multirow{2}{*}{$\chi^{2}$} & $\mathrm{P}$ \\
\cline { 2 - 7 } & $\mathrm{n}^{*}$ & $\%$ & $\mathrm{n}$ & $\%$ & $\mathrm{n}$ & $\%$ & & \\
\hline Male & $4 / 14$ & 26.8 & $4 / 16$ & 25.0 & $8 / 30$ & 26.7 & 0.049 & 1.000 \\
Female & $3 / 13$ & 23.1 & $3 / 11$ & 27.3 & $6 / 24$ & 25.0 & 0.056 & 1.000 \\
Total & $7 / 28$ & 25.0 & $7 / 27$ & 25.9 & $14 / 55$ & 25.5 & 0.006 & 1.000 \\
\hline$\chi^{2} ;$ df:1 & 0.048 & 0.018 & 0.005 & & \\
$\mathrm{P}$ & 1.000 & 1.000 & 1.000 & & \\
\hline
\end{tabular}

*n: number of cases with epicondylitis /number of analyzed individuals.

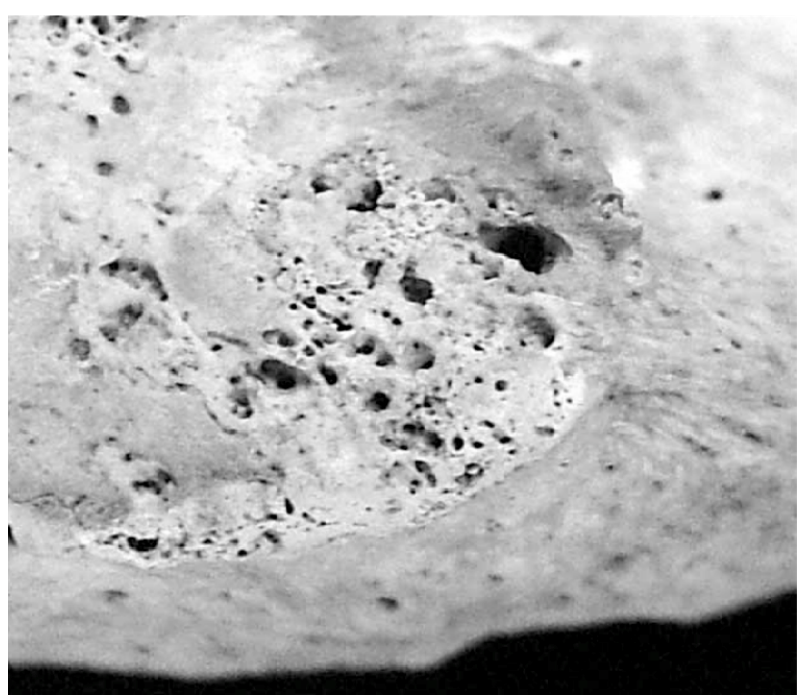

Figure 3.

Close-up view of the bony pits-The rounded edges show evidence of the healing process. The pits without rounded edges suggest more recent trauma.

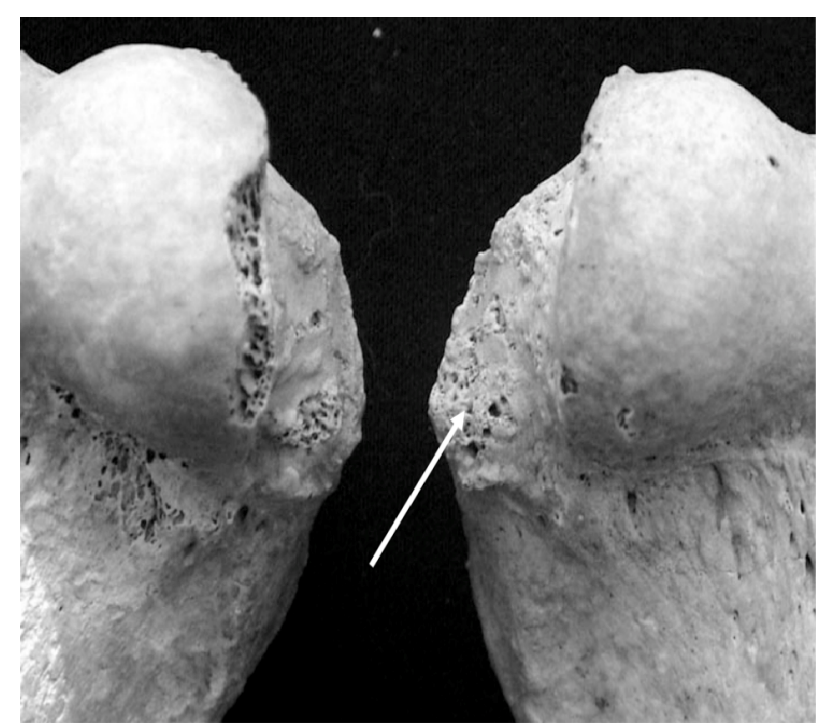

Figure 4.

Right and left lateral epicondyles of KK'02 SK 7/2. The arrow points to pits on right-The left shows fewer pits and a small endosthese. 
groups (Table 2). Half of the individuals in this group have medial epicondylitis. The distribution of epicondylitis in relation to age groups follows a similar path for the left and right humerii and does not demonstrate a statistically significant difference. There were no significant differences in distribution of epicondylitis between the left and right humerii.

Lateral epicondylitis (Figure 5) was identified by noted bumps, irregular grooves, and lateral cicatrical dimples on the lateral epicondyles, but few pits were observed, suggesting there was no tearing of the tendon. Figure 6 shows the bony pits created by the pulling away of the tendon from the left lateral epicondyle, also a small enthesis. A close-up view of the left lateral epicondyle (Figure 7) shows few pits but some endostheses. Some pits have rounded edges suggestive of healing, but others have no rounding, indicating a more recent tear with no remodelling.

The frequency of lateral epicondylitis among the Kovuklukaya population $(69.4 \%)$ was higher and greater among females $(73.9 \%)$ than males $(64.4 \%)$ but did not reach statistical significance. The frequency of lateral epicondylitis on the right side was the same for males and females, but on the left humerus it was higher in females (see Table 3).

Table 2.

Distribution of medial epicondylitis in relation to age.

\begin{tabular}{|c|c|c|c|c|c|c|c|c|}
\hline & \multicolumn{2}{|c|}{ Right } & \multicolumn{2}{|c|}{ Left } & \multicolumn{2}{|c|}{ Total } & \multirow{2}{*}{$\chi^{2}$} & \multirow{2}{*}{$\mathrm{P}$} \\
\hline & $\mathrm{n}^{*}$ & $\%$ & $\mathrm{n}$ & $\%$ & $\mathrm{n}$ & $\%$ & & \\
\hline $\begin{array}{l}\text { Young } \\
\text { Adult }\end{array}$ & $0 / 3$ & 0.0 & $0 / 2$ & 0.0 & $0 / 5$ & 0.0 & - & - \\
\hline $\begin{array}{l}\text { Middle } \\
\text { Adult }\end{array}$ & $4 / 8$ & 50,0 & $4 / 8$ & 50.0 & $8 / 16$ & 50.0 & 0.000 & 1.000 \\
\hline $\begin{array}{c}\text { Old } \\
\text { Adult }\end{array}$ & $3 / 17$ & 17.6 & $3 / 17$ & 17.6 & $6 / 34$ & 17.6 & 0.000 & 1.000 \\
\hline Total & $7 / 28$ & 25.0 & $7 / 27$ & 25.9 & $14 / 55$ & 25.5 & 0.006 & 1.000 \\
\hline$\chi^{2}(\mathrm{df}: 2)$ & \multicolumn{2}{|c|}{4.157} & \multicolumn{2}{|c|}{3.721} & \multicolumn{2}{|c|}{7.880} & & \\
\hline $\mathrm{P}$ & \multicolumn{2}{|c|}{0.125} & \multicolumn{2}{|c|}{0.156} & \multicolumn{2}{|c|}{0.019} & & \\
\hline
\end{tabular}

${ }^{*} \mathrm{n}$ : number of cases with epicondylitis /number of analyzed individuals.

Table 3.

Distribution of lateral epicondylitis according to sex.

\begin{tabular}{|c|c|c|c|c|c|c|c|c|}
\hline & \multicolumn{2}{|c|}{ Right } & \multicolumn{2}{|c|}{ Left } & \multicolumn{2}{|c|}{ Total } & \multirow{2}{*}{$\chi^{2}$} & \multirow{2}{*}{$\mathrm{P}$} \\
\hline & $\mathrm{n}^{*}$ & $\%$ & $\mathrm{n}$ & $\%$ & $\mathrm{n}$ & $\%$ & & \\
\hline Male & $9 / 13$ & 69.2 & $8 / 13$ & 61.5 & $17 / 26$ & 64.4 & 0.170 & 1.000 \\
\hline Female & $9 / 13$ & 69.2 & $8 / 10$ & 80.0 & $17 / 23$ & 73.9 & 0,340 & 0.660 \\
\hline Total & $18 / 26$ & 69.2 & $16 / 23$ & 69.6 & $34 / 49$ & 69.4 & 0.001 & 1.000 \\
\hline$\chi^{2}$ & \multicolumn{2}{|c|}{0.000} & \multicolumn{2}{|c|}{0.910} & \multicolumn{2}{|c|}{0.418} & & \\
\hline P: & \multicolumn{2}{|c|}{1.000} & \multicolumn{2}{|c|}{0.405} & \multicolumn{2}{|c|}{0.552} & & \\
\hline
\end{tabular}

${ }^{*}$ n: number of cases with epicondylitis/ number of analyzed individuals.

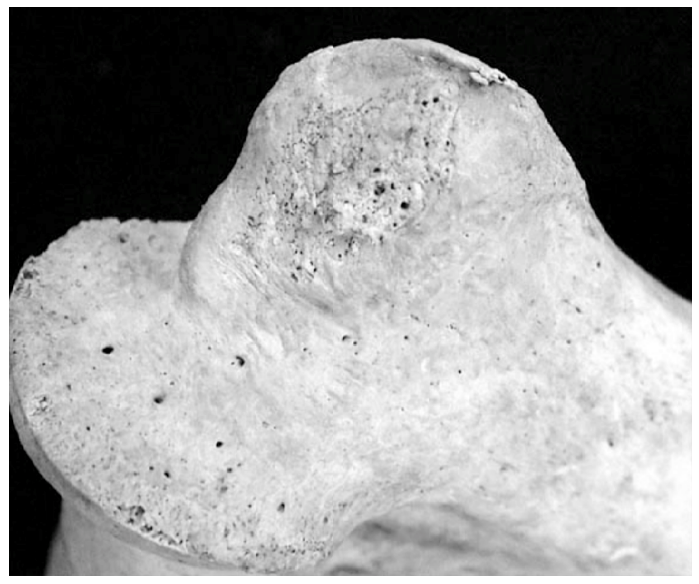

Figure 5.

Left medial epicondyle with endostheses but few pitssuggesting epicondylitis although tendon was not avulsed.

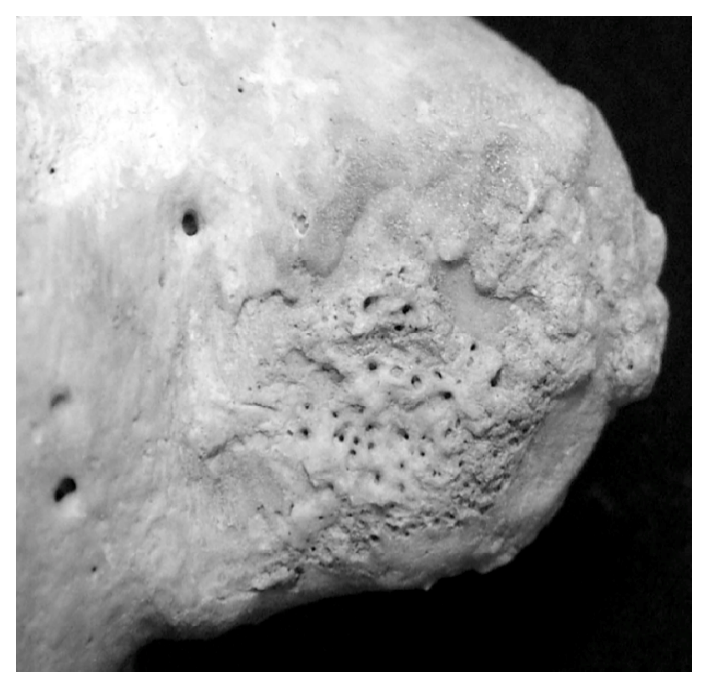

Figure 6.

Close up view of right medial epicondyle of KK'02 SK 7/2. The raised entheses are visible, as is the pitting where bony attachments avulsed when the tendon tore.

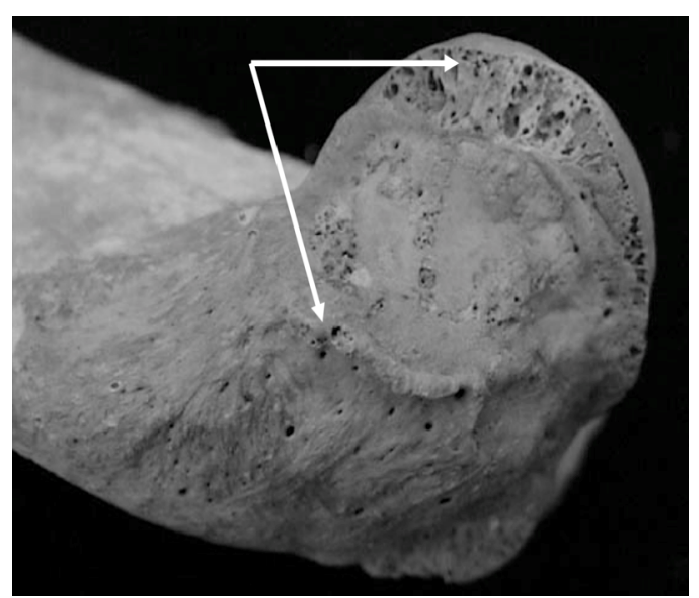

Figure 7.

Left lateral epicondyle showing the bony pits created by the pulling away of the tendon and the endostheses. 
As observed on medial epicondylitis, no young adults were diagnosed with lateral epicondylitis, but more than half of the middle-aged and almost all older individuals (approximately 90\%) had this lesion (Table 4). The collected data show lateral epicondylitis is a lesion advancing with age (Table 4). The frequency of this condition across different age groups is statistically significant.

\section{Discussion}

Studies of present day individuals shows that repetitive or forceful tasks create a risk of epicondylitis (Marklin \& Monroe, 1998; Pascarelli \& Hsu, 2001). There is an association between epicondylitis and sport activities (e.g. tennis, golf, and baseball, cf. Priest et al., 1977) and daily activities such as meat processing, woodcutting, shoemaking, and glassblowing (Vukovic et al., 2004; Werner et al. 2005), where workers are required to undertake repetitive or forceful tasks. Kurppa et al. (1991) found the incidence of epicondylitis in a meat-processing factory was up to 11 times greater than the normal population. O'Dwyer and Howie (1995) studied 95 cases of medial epicondylitis and noted that $90 \%$ were related to work and only $10 \%$ to sport or leisure activities.

Epicondylitis has been used in a very limited way in studies aimed at the identification of life style in the ancient human populations (Peterson 1997). Miller (1985) conducted an early study on lateral epicondylitis, but its prevalence was not given. Crianni and Fornaciari (2003) studied the skeleton of the $18^{\text {th }}$ century cellist Boccherini and their combined macroscopic and radiographic assessment showed that acquired muscle-skeletal lesions related to activity. The joint of the left elbow revealed bumps, irregular grooves and lateral cicatrical dimples suggesting chronic epicondylitis.

Medial epicondylitis is less common and is caused by sports needing strong flexion of the hand and fingers e.g. baseball, javelin throwing, weight lifting, volleyball, climbing, tennis, or golf (Priest et al., 1977; Walker-Bone et al., 2004). Priest et al. (1977) examined 84 prominent and skilled tennis players, 54 men and 30 women. Elbow symptoms were experienced by $45 \%$ at some time during their playing careers, and $37 \%$ had symptoms that were major, lasting weeks to 15 years. Eleven of the players experienced lateral epicondylitis and twelve had medial epicondylitis.

In the Kovuklukaya population medial epicondylitis was diagnosed in $25.5 \%$ and lateral epicondylitis in $69.3 \%$ of the studied humerii, demonstrating that the forearms of the individuals were subjected to either major repetitive or severe physical stress. We found no significant difference between the sexes in the frequency of epicondylitis, suggesting that both sexes in this population were subjected to similar stress levels. Medial epicondylitis was commoner in males whereas lateral epicondylitis was commoner in females.

There is no archaeological evidence to explain these changes, however, the ecological characteristics of the present day Boyabat district and the traditional life styles of the inhabitants enable us to draw some conclusions (Erdal, 2004). Arable land is scarce, grains raised in villages barely satisfies the needs of the people (Başoglu, 1972). Mountainous regions, forests and shrubs account for $62 \%$ of the land. The mountains surrounding Boyabat are covered with pines and oaks, and they provide the best lumber in Anatolia, hence, lumber production constitutes the major source of subsistence in the region.
Table 4.

Distribution of lateral epicondylitis in relation to age groups.

\begin{tabular}{cccccccccc}
\hline & \multicolumn{2}{c}{ Right } & \multicolumn{2}{c}{ Left } & \multicolumn{2}{c}{ Total } & \multirow{2}{*}{$\chi^{2}$} & $\mathrm{P}$ \\
\cline { 2 - 6 } & $\mathrm{n}^{*}$ & $\%$ & $\mathrm{n}$ & $\%$ & $\mathrm{n}$ & $\%$ & & \\
\hline $\begin{array}{c}\text { Young } \\
\text { Adult }\end{array}$ & $0 / 3$ & 0,0 & $0 / 2$ & 0,0 & $0 / 5$ & 0.0 & - & - \\
$\begin{array}{c}\text { Middle } \\
\text { Adult }\end{array}$ & $5 / 8$ & 62.5 & $4 / 8$ & 50.0 & $9 / 16$ & 56.3 & 0.256 & 1.000 \\
$\begin{array}{c}\text { Older } \\
\text { Adult }\end{array}$ & $13 / 15$ & 86.7 & $12 / 13$ & 92.3 & $25 / 28$ & 89.3 & 0.232 & 1.000 \\
Total & $18 / 26$ & 69.2 & $16 / 23$ & 69.6 & $34 / 49$ & 69.4 & 0.001 & 1.000 \\
\hline$\chi^{2}$ (df:2) & 9.061 & & 9.194 & & 17.853 & & & \\
$\mathrm{P}$ & 0.011 & & 0.010 & & 0.000 & & & \\
\hline
\end{tabular}

* n: number of cases with epicondylitis /number of analyzed individuals.

Seventy one percent of the male individuals in the sample had some rib, coxae, Colles', finger, femur, tibia and patella fractures - all related to tree felling (Erdal, 2004). Vukovic et al. (2004) point to the existence of a relationship between epicondylitis and woodcutting, with the use of axe and saw putting stress on elbows and fingers. The gripping of an axe requires finger flexion, identical to tennis players gripping a racket. Flexion and extension are also relevant when using a saw.

Epicondylitis on males may have been caused by activities such as tree felling, lumber production, and carrying timber. Ethnographic and archaeological data suggest different reasons for epicondylitis in females. Miller (1985) noted that combination of flexion and extension, partial pronation, and prolonged tension of the forearm musculature is needed to produce a prominent lateral epicondylar enthesis. These pathological changes were seen in the Nuvakwewtaga people in the Southeast United States and attributed to grinding maize. This sequence of movements shows similarity to the movement system of the arms, during textile production on ground-looms. Mesiodistally directed grooves on the anterior dentition of females from Kovuklukaya were observed (Erdal, 2008). According to the unusual abrasion on anterior dentition and the ethnographic data, it is concluded that Kovuklukaya females used their anterior dentition during yarn production. Weaving on a horizontal ground-loom is a typical activity of women in this region from early times to the present. The horizontal ground-loom has its warp stretched between two beams fastened to two or four pegs driven into the ground. Warp is put directly on the warp beams and transferred to the loom later. The warp threads are divided into two layers, half of which (the odd threads) are lashed to a stick tied above the warp (the rod-heddle). When this rod-heddle is raised a space, the shed, is formed through which the weft can be passed. To obtain the "counter-shed" for the next passage of the weft, the even threads must be raised by means of shed-rod, a piece of wood turned on edge. For this action to be performed, the wooden instrument used for beating the weft is forcefully pushed forward and pulled back with both arms. Therefore, in textile production, a combination of flexion and extension, partial pronation, and prolonged tension of the forearm musculature occurs as fingers and thumbs tightly hold the beating instrument. For a diagram and details of textile production on horizontal ground-loom, see Barber (1991: 79-91) and Forbes (1956: 192-195).

The above, taken together with finding of high prevalence 
rates of both lateral and medial epicondylitis in the Kovukkaya sample, imply that these pathological changes were caused in males by the use of an axe, and in females by yarn and textile production on ground-looms as well as grinding of cerealsactivities that require the continuous use of both hands. Therefore, the lack of statistically significant differences between the right and left epicondylitis in the Kovuklukaya population can be explained. However the pitting and enthesopathies on the right side were more severe indicating more stress on the dominant right arm.

The risk of developing medial epicondylitis is much higher in the presence of lateral epicondylitis (Walker-Bone et al., 2004), which may contribute to the high incidence of medial epicondylitis among the Kovuklukaya population. Lateral epicondylitis is most frequently observed among individuals approximately aged 45 - 54 years (Walker-Bone et al., 2004). The increasing prevalence of lateral epicondylitis in Kovuklukaya with age resembles this modern pattern. The greater proportion of older females in Kovuklukaya (females lived on average 6 years more than males and demonstrated an average of 49.5 years of age at death) may explain the higher frequency of lateral epicondylitis among females.

\section{Conclusion}

The frequency of medial and lateral epicondylitis was high in the $8^{\text {th }}-10^{\text {th }}$ century Byzantine Kovuklukaya population and indicates a similarity of the movements of the forearm and fingers of these individuals to modern-day golf and tennis players. Repetitive activities such as using an axe, producing yarn, and weaving textile on a ground-loom are consistent with the flexion, extension and pronation of the arms, which today are characteristic injuries of golf and tennis, amongst a range of other activities.

In studies oriented towards identifying the life style in ancient human societies, the presence of epicondylitis is a useful indication of activity patterns in archaeological populations. Analyzing these occupational markers on a population-based level may in certain instances help us understand division of labour in relation to (1) sex, (2) social complexity and (3) age. This study therefore highlights the potential of accurate pathological diagnosis of these conditions in skeletal series in conjunction with available archaeological and osteological data regarding sex, age, status, other pathologies and various additional indicators of the activities of past populations.

\section{Acknowledgements}

We acknowledge the help of Professor Israel Hershkovitz of Tel Aviv University and for the $\mathrm{C}^{14}$ dating, Dr. Elisabetta Boaretto, Radiocarbon Dating Laboratory, Weizmann Institute of Science, Rehovot, Israel. We thank the Director of Sinop $\mathrm{Mu}-$ seum, Musa Ozcan, and the Museum assistant Fuat Dereli for permission to work on the Kovuklukaya skeletal material.

\section{REFERENCES}

Al-Oumaoui, I., Jiménez-Brobeil, S., \& du Souich, P. (2004). Markers of activity patterns in some populations of the Iberian Peninsula. International Journal of Osteoarchaeology, 14, 343-359.

Bannister, L. H., Berry, M. M., Collins, P., Dyson, M., Dussek, J. E., \& Ferguson, M. W. J. (1995). In: Gray's Anatomy, 38th edition (pp. 512-515). Edinburgh: Churchill-Livingstone.
Barber, E. J. W. (1991). Prehistoric textile: The development of cloth in the Neolithic and Bronze Ages with special reference to the Aegean. Princeton: Princeton University Press.

Barton, N. J., Hooper, G., Noble, J., \& Steel, W. M. (1990). Report of BOA Working Party on occupational causes of upper limb disorders. London: British Orthopaedic Association.

Basoglu, B. (1972). Boyabat ve Çevresi Tarihi. Ankara: British Institute at Ankara.

Benjamin, M., Kumai, T., Milz, S., Boszczyk, B. M., Boszczyk, A. A., \& Ralphs J R. 2002. The skeletal attachment of tendons-Tendon "enthuses". Comparative Biochemistry and Physiology Part A: Molecular \& Integrative Physiology, 133, 931-945. doi:10.1016/S1095-6433(02)00138-1

Brooks, S., \& Suchey, J. M. (1990). Skeletal age determination based on the os pubis: A comparison of the Ascadi-Nemeskeri and SucheyBrooks methods. Human Evolution, 5, 227-238. doi:10.1007/BF02437238

Buikstra, J., \& Uberlaker, D. H. (1994). Standards for data collection from human skeletal remains. Proceedings of a seminar at the Field Museum of Natural History, Fayetteville: Arkansas Archaeological Survey.

Cardoso, F. C., \& Henderson, C. Y. (2010). Enthesopathy formation in the humerus: Data from known age-at-death and known occupation skeletal collections. American Journal of Physical Anthropology, 141, 550-560.

Chapman, N. E. M. (1997). Evidence for Spanish influence on activity induced musculoskeletal stress markers at Pecos Pueblo. International Journal of Osteoarcheology, 7, 497-506. doi:10.1002/(SICI)1099-1212(199709/10)7:5<497::AID-OA394>3.0 .CO;2-H

Claudepierre, P., \& Voisin, M.-C. (2005). The entheses: Histology, pathology, and pathophysiology. Joint Bone Spine, 72, 32-37. doi:10.1016/j.jbspin.2004.02.010

Crianni, R., \& Fornaciari, G. (2003). Luigi Boccheriniand the Barocco Cello: An 18th Century striking case of occupational disease. International Journal of Osteoarchaeology, 13, 294-302. doi:10.1002/oa.701

Crubézy, E., Goulet, J., Bruzek, J., Jelinek, J., Rouge, D., \& Ludes, B. (2002). Epidemiology of osteoarthritis and enthesopathies in a European population dating back 7700 years. Joint Bone Spine, 69, 580-588. doi:10.1016/S1297-319X(02)00455-4

Erdal, Y. S. (2004). Kovuklukaya (Boyabat/Sinop) İnsanlarının Sağlık Yapısı ve Yaşam Biçimleriyle İlişkisi. Anadolu Arastirmalari, 17, 169-176.

Erdal, Y. S. (2008). Occlusal grooves in anterior dentition among Kovuklukaya inhabitants (Sinop, Northern Anatolia, 10th century AD). International Journal of Osteoarchaology, 18, 152-166. doi:10.1002/oa.925

Eshed, V., Gopher, A., Galili. E., \& Hershkovitz, I. (2004). Musculoskeletal stress markers in Natufian hunter-gatherers and Neolithic farmers in the Levant: The upper limb. American Journal of Physical Anthropology, 123, 303-315. doi:10.1002/ajpa.10312

Forbes, R. J. (1956). Studies ancient technology, Volume IV. Ledien: E.J. Brill.

Havelokova, P., Villotte, S., Velemínský, P., Poláček, L. \& Dobisíková, M. (2011). Enthesopathies and activity patterns in the Early Medieval Great Moravian population: Evidence of division of labour. International Journal of Osteoarchaeology, 21, 487-504.

Gore, R. M., Rogers, L. F., Bowerman, J., Suker, J., \& Compere, C. L. (1980). Osseous manifestations of elbow stress associated with sports activities. American Journal of Roentgenology, 134, 971-977.

Hawkey, D. E., \& Merbs, C. F. (1995). Activity-induced musculoskeletal stress markers (MSM) and subsistence strategy changes among ancient Hudson Bay Eskimos. International Journal of Osteoarchaeology, 5, 324-338. doi:10.1002/oa.1390050403

Kurppa, K., Viikari-Juntura, E., Kuosma, E., Huuskonen, M., \& Kivi, P. (1991). Incidence of tenosynovitis or peritendinitis and epicondylitis in a meat-processing factory. Scandinavian Journal of Work, Environment and Health, 17, 32-37. doi:10.5271/sjweh.1737

Larsen, C. S. (1995). Biological changes in human populations with 
agriculture. Annual Review of Anthropology, 24, 185-213. doi:10.1146/annurev.an.24.100195.001153

Lovejoy, C. O., Meindl, R. S., Pryzbeck, T. R., \& Mensforth, R. P. (1985). Chronological metamorphosis of the auricular surface of the ilium: A new method for the determination of adult skeletal age at death. American Journal of Physical Anthropology, 68, 15-28. doi:10.1002/ajpa.1330680103

Marklin, R. W., \& Monroe, J. F. (1998). Quantitative biomechanical analysis of wrist motion in bonetrimming jobs in the meat packing industry. Ergonomics, 41, 227-237.

doi: $10.1080 / 001401398187279$

Masmejean, E., Dutour, O., Touam, C., \& Oberlin, C. (1997). SLAC wrist bilatéral: Une entité à part: À propos d'un cas préhistorique de 7000 ans. Annales de Chirurgie de la Main et du Membre Supérieur, 16, 207-214. doi:10.1016/S0753-9053(97)80003-8

Meindl, R. S., \& Lovejoy, C. O. (1985). Ectocranial suture closure: A revised method for the determination of skeletal age at death based on the lateral-anterior sutures. American Journal of Physical Anthropology, 68, 57-66. doi:10.1002/ajpa.1330680106

Meindl, R. S., \& Lovejoy, C. O. (1989). Age changes in the pelvis: Implication for paleodemography. In M. Y. Ișcan (Ed.), Age markers in the human skeleton (pp. 137-168). Springfield, Illinois: Charles C Thomas.

Miles, A. E. W. (1996). Humeral impingement on the acromion in a Scottish island population of c.1600 AD. International Journal of Osteoarchaeology, 6, 259-288. doi:10.1002/(SICI) 1099-1212(199606)6:3<259::AID-OA270>3.0.C $\underline{\mathrm{O} ; 2-5}$

Miles, A. E. W. (1999). A five-grade categorization of age-related change in the acromioclavicular joint derived from the skeletal remains of early 19th century Londoners of known sex and age. International Journal of Osteoarchaeology, 9, 83-101. doi:10.1002/(SICI)1099-1212(199903/04)9:2<83::AID-OA461>3.0. $\mathrm{CO} ; 2-\mathrm{V}$

Miller, R. J. (1985). Lateral epicondylitis in the prehistoric indian population from Nuvakwewtaqa (Chavez Pass), Arizona). In C. F.
Merbs and R. J. Miller (Eds.), Health and diseases in the prehistoric southwest (pp. 391-400). Phoenix metropolitan area, Arizona: Arizona State University.

Molnar, P. (2006). Tracing prehistoric activities: Muskuloskeletal stress marker analysis of a Stone-Age population on the island of Gotland in the Baltic Sea. American Journal of Physical Anthropology, 129, 12-23. doi:10.1002/ajpa.20234

Niepel, G. A., \& Sit'aj, S. (1979). Enthesopathy. Clinics in Rheumatic Diseases, 5, 857-872.

O'Dwyer, K. J, \& Howie, C. R. (1995). Medial epicondylitis of the elbow. International Orthopaedics, 19, 69-71.

Pascarelli, E. F., \& Hsu, Y. P. (2001). Understanding work-related upper extremity disorders: Clinical findings in 485 computer users, musicians, and others. Journal of Occupational Rehabilitation, 11, 121. doi:10.1023/A:1016647923501

Peterson, J. (1997). Tracking activity patterns through skeletal remains: A case study from Jordan and Palestine. In H. G. K. Gebel, Z. Kafafi, \& G. O. Rollefson (Eds.), The prehistory of Jordan II. Perspectives from 1997. Studies in Early Near Eastern production, subsistence, and environment 4 (pp. 475-492). Berlin: Ex Oriente.

Priest, J. D., Jones, H. H., Tichenor, C. J. C., \& Nagel, D. A. (1977). Arm and Elbow Changes in Expert Tennis Players. Minnesota Medicine, 60, 399-404.

Stirland A. (1991). Diagnosis of occupationally related paleopathology. Current syntheses and future options. Washington: Smithsonian.

Vuković, S., Krstev, S., \& Maksimović, M. (2004). Diseases of the locomotor system in forestry workers. Srpski Arhiv za Celokupno Lekarstvo, 132, 246-249 (in Serbian).

Walker-Bone, K., Palmer, K. T., Reading, I., Coggon, D., \& Copper, C. (2004). Prevalence and impact of musculoskeletal disorders of the upper limb in the general population. Arthritis and Rheumatism, 51, 642-651. doi:10.1002/art.20535

Werner, R. A., Franzblau, A., Gell, N., Hartigan, A., Ebersole, M., \& Armstrong, T. J. (2005). Predictors of persistent elbow tendonitis among auto assembly workers. Journal of Occupational Rehabilitation, 15, 393-400. doi:10.1007/s10926-005-5945-6 